\title{
DETERMINANTS OF CONTACTLESS CREDIT CARDS ACCEPTANCE IN TURKEY
}

\author{
Ph.D. Kemal EYÜBOĞLU* \\ Karadeniz Technical University, SBE, (keyuboglu@ktu.edu.tr) \\ Asst. Prof. Uğur SEVIM \\ Giresun University, IİBF, (ugursevim@yahoo.com)
}

\begin{abstract}
The purpose of the study is to provide an insight into the determinants of individuals' contactless credit cards acceptance. We developed a theoretical model based on the Technology Acceptance Model (TAM) with added constructs perceived risk and perceived playfulness empirically, and tested its ability in predicting individuals' behavioral intention to use contactless credit cards. We designed a survey and obtained 695 usable responses. We analyzed the data using Structured Equation Modeling (SEM) to evaluate the strength of the causal relationships. The results indicate that perceived ease of use has a direct and perceived usefulness has an indirect effect on the acceptance of contactless credit cards. Also perceived risk and perceived playfulness have an effect but it is insignificant.
\end{abstract}

Keywords: Technology Acceptance Model, Contactless Credit Cards, Structural Equation Modeling, Turkey.

\section{TÜRKIYY'DE TEMASSIZ KREDİ KARTI KULLANIMINI ETKILEYEN FAKTÖRLER}

\begin{abstract}
ÖZET
Bu çalışmanın amacı bireylerin temassız kredi kartı kullanımını etkileyen faktörlerin belirlenmesidir. Bu amaçla Teknoloji Kabul Modeli'ne algllanan risk ve algllanan e ğlenebilirlik değişkenleri eklenerek bir model oluşturulmuştur. Veri toplamak amacıyla bir anket formu hazırlanmış ve 695 kullanılabilir veri elde edilmiştir. Elde edilen veriler Yapısal Eşitlik Modeli ile analiz edilmistir. Elde edilen sonuçlar algılanan kullanım kolaylı̆̆ının kullanım niyeti üzerinde doğrudan, algılanan kullanışlılı̆̆ın ise dolaylı etkisi olduğunu göstermiştir. İlaveten algılanan risk ve algılanan ĕ̆lenebilirlik değişkenlerinin kullanım niyeti üzerinde etkisi olmadiğ tespit edilmiştir.
\end{abstract}

Anahtar Kelimeler: Teknoloji Kabul Modeli, Temassız Kredi Kartı, Yapısal Eşitlik Modeli, Türkiye.

\footnotetext{
* Corresponding author.
} 


\section{Introduction}

Contactless smart cards have emerged in recent years as a kind of electronic tag. They have routinely been used in the fields of electronic ticketing, transportation and access control. Currently, contactless smart cards are used for electronic payment transactions. The most important difference between the contact and contactless cards is that contactless cards don't need to place the card in the slot of a smart card reader. The transmission takes place through a link of radio frequency ${ }^{1}$ instead of through electrical contacts located on the smart card module. This frequency transmission is established via a chip which is embedded in the smart card (Handschuh, 2004). There are a number of studies in the market to add options for making payments via contactless smart cards which provides important advantages for all stakeholders. Some benefits of contactless payments are (Smart Card Alliance, 2007):

- Consumers find the contactless cards' speed and convenience more attractive in comparison to contact cards. Consumers don't need to carry cash for small amounts of payments nor do they have to swipe their cards.

- Finance companies are able to increase the volume of transaction by seizing cash made transactions with contactless payments.

- Contactless payments are subjected to ISO/EEC14443 safety standards which have existed worldwide over 40 years to develop ways of payments and existing financial payments.

- Contactless payments are supported by the world leading brands like American Express, Discover Network, Master Card and Visa. Over 17 million contactless cards have been issued by some of the largest companies in the US and the rest of the world since mid2005.

- Contactless payments have been accepted by a large range of retail sectors, in which speed and convenience are particularly important in commercial service model. Nowadays, more than 35,000 retail outlets accept contactless payment cards and devices. Commercial adoption of contactless payments has contributed to higher commercial volume and increased in spending per transaction.

- From the security view, according to the existing security measures of the traditional payment cards, new security measures have been added to contactless cards to reduce the possible risk and create a new combined security system. Also, contactless card holders are protected by specially developed (software) programs, which are developed by the card manufacturers and the banks for misuse and fraud.

However all these advantages and positive features, it is an important fact that contactless cards have not widely been used. For example, in US and England, lower than 5\% of contactless card holders use their contactless cards in the payment of transactions (Christiansen, 2011).

1 Radio frequency (RF) waves are the frequencies within the electromagnetic spectrum associated with radio wave propagation. Many wireless communications technologies are based on RF, including radio, television, mobile phones, wireless networks and now, contactless payment cards and devices (Smart Card Alliance, 2007:2). 
Contactless card usage and related payments have gradually been increasing in Turkey. More than 20 million cards, $22 \%$ of the credit cards and 7\% of the debit cards have the contactless function in Turkey. According the data of 2014 in Turkey, out of 30 million annual transactions, 300 million TL was spent as a result of using contactless transaction and that shows $10 \mathrm{TL}$ valuing contactless payment for each contactless transaction (Haberturk, 2015). The purpose of the study is to provide an insight into the determinants of individuals' contactless credit cards acceptance in Turkey. This paper is organized as follows. Section 2 explains Technology Acceptance Model. Section 3 provides an overview of the literature. Section 4 describes the data and explains the methodology and presents the empirical results and Section 5 includes conclusion.

\section{Technology Acceptance Model (TAM)}

Several models have been developed for the determination which factors are affecting the acceptance of information systems. The theoretical models employed to study for example Theory of Reasoned Action (TRA) (Ajzen and Fishbein, 1980), the Theory of Planned Behavior (TPB) (Ajzen, 1991; Mathieson, 1991), and the Technology Acceptance Model (TAM) (Davis, 1989; Davis et al. 1989). However, current study has focused on the TAM because of previous studies has shown that the TAM explains a higher level of variance in systems use than the TRA, TPB (Pikkarainen et al. 2004; Lee et al. 2003).

Generally, the goal of TAM is "to provide an explanation of the determinants of computer acceptance that is in general, capable of explaining user behavior across a broad range of end-user computing technologies and user populations, while at the same time being both parsimonious and theoretically justified." (Davis et al. 1989). TAM consists of perceived usefulness (PU), perceived ease of use (PEOU), attitude (A) and the behavioral intention of the use (BI) components (Figure 1). Davis (1989) defines PU as "the degree to which a person believes that using a particular system would enhance his or her job performance", PEOU as "the degree to which a person believes that using a particular system would be free of effort". According to TAM, BI is a major determinant of usage behavior; behavior can be predicted by measuring BI. BI is viewed as being jointly determined by the person's attitude toward using the system A and PU. PU and PEOU have been hypothesized to have positive influences on A. PEOU influences attitudes and behavior through two mechanisms: self-efficacy and instrumentality. This means the easier the system is to use, the greater will be the user's efficacy felt to be regarding his or her capacity to use the system. To the extent that increased PEOU leads to improved performance, PEOU will have a direct influence on PU. External variables represented in TAM provides a bridge between the internal beliefs (PU and PEOU), attitude (A) and behavioral intentions (BI) and various individual differences, situational constraints, organizational characteristics and system characteristics impacting on behavior. Just as Davis et al. (1989) demonstrated: "A key purpose of TAM, is to provide a basis for tracing the impact of external factors on internal beliefs, attitudes, and intentions." 
Figure 1: Technology Acceptance Model

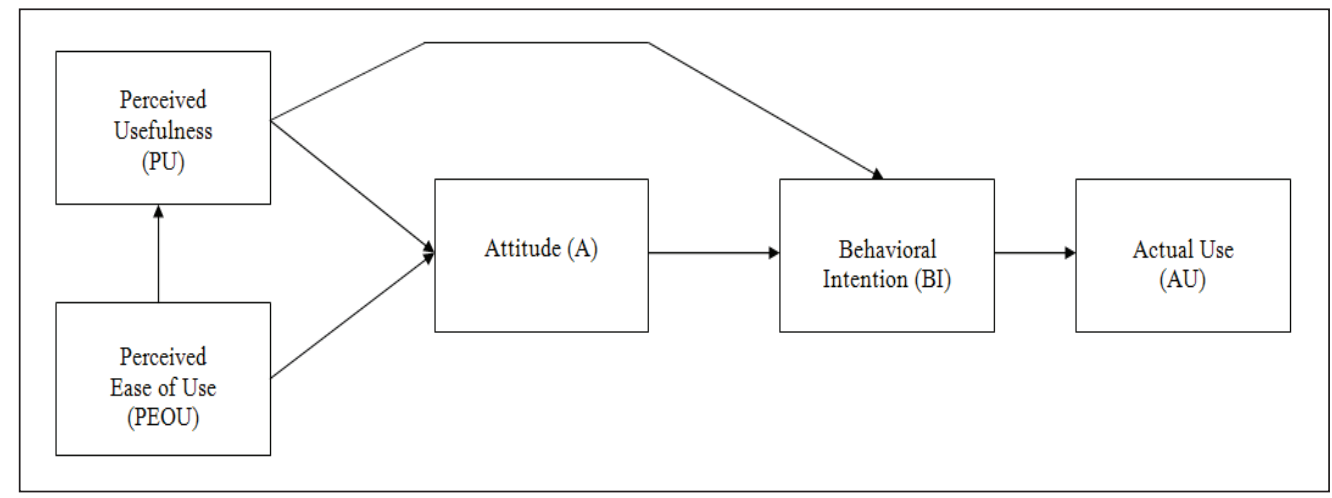

Source: Davis, F. D., Bagozzi, R. P. \& Warshaw, P. R. (1989). User acceptance of computer technology: A comparison of two theoretical models. Management Science, 35(8), 982-1003.

\section{Literature Review}

Contactless credit card is a new information technology hence there are limited studies in the topic of contactless payment activities of individuals in the literature. In these studies; Karaiskos et al. (2007) examined determining factors of individuals' acceptance of the contactless RFID ticketing system. The results showed that the PU and PEOU were the strong factors for the acceptance to use the information system. Wang (2008) researchedthe factors which affected individuals' adoption of contactless credit cards. The results indicated that PU, PEOU, PR and trust factors had no considerable impact on individuals' intention to use it. However, compatibility and loyalty had an important role on individuals' adoption to contactless credit cards. Also, he emphasized that the most important factor for contactless card usage was the availability of infrastructure. Taherdoost \& Masrom (2009) developed an adoption model for using smart card technology and defined the important factors which contribute an increase in participation on this developed model. They concluded that the factors such as lack of user acceptance, education and end-user support were the most important obstacles for the success of new data systems. Also, it was stated that culture had a vital role in technology acceptance. Polasik et al. (2010) examined the factors that effecting individuals' acceptance of contactless credit cards. The results showed that PU and PEOU had a considerable impact on individuals' payment preference. Wu et al. (2012) investigated the factors that had an effect on the acceptance of I Pass (a ticket system used in public transport system in Koahsiung). The study indicated that expectancy and social influence factors which had significant and positive impact on behavioral intention; facilitating conditions had a positive impact on intention to use. Trutsch (2014) searched the effect of contactless cards on sales volume. Results indicated that payment innovations such as contactless credit cards and debit cards lead an increase in sales volume approximately 8\%-10\%. Fiedler \& Ozturen (2014) analyzed the factors that had an effect on the acceptance of contactless payment. They found that PEOU and PU had an effect on acceptance of contactless payment. Also knowledge level had a strong impact on PU and PEOU and age which is an exogenous variable had an empirical impact on PU. In addition, the study stated that gender and education variables had not a strong impact on PU and PEOU. Also 
Harper (2014) examined the factors which had impact on individuals' adoption to alternative payment systems and he concluded that PEOU and PU were the most prominent factors for the acceptance of a new payment technologies. Also he found security was an important factor in the use of new payment technologies.

\section{Research Model and Hypothesis}

The research model investigates the factors that have an effect on individuals' adoption to contactless credit cards. Mathieson (1991) indicate that the key variables of TAM are insufficient for predicting the intention to use hence other variables should be included into the model. Therefore we added PR and PP, to the original TAM in order to strengthen the model. Especially in the electronic commerce and contactless credit card usage, one of the most important issues is the risk. Users can confront with a variety of risk factors such as disclosure of personal information and stolen of card information hence they want to feel safety. Therefore PR variable has been included in the research model. In addition it has been also observed that PR is used in many different studies which are examining adoption to information systems such as mobile payments (Shin \& Lee, 2014), contactless credit cards (Wang, 2008; Harper, 2014), e-shopping (Zheng et al., 2012). The PP variable is associated with the determination of the individuals' considerations about entertainment function of the contactless credit card usage. Especially in the area of electronic commerce PP has been used in many different areas such as web context (Lin et al, 2005), e-learning (Calli et al., 2013) and mobile payment (Ho et al., 2013). The research model is shown in Figure 2. Based on the theoretical model developed below, we formulate the research hypotheses as follows.

Figure 2: Research Model

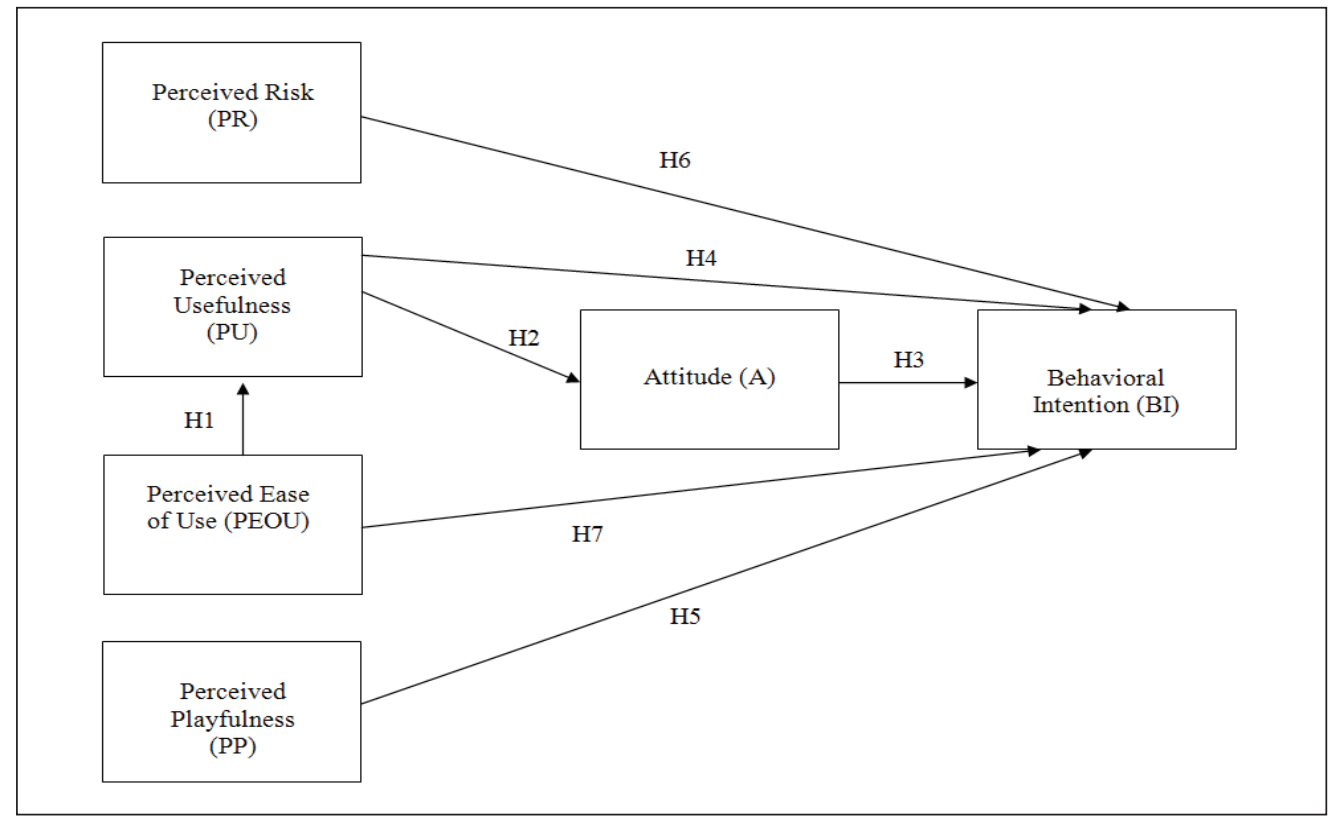


H1: An individual's perceived ease of use has a positive impact on individual's perceived usefulness.

H2: An individual's perceived usefulness has a positive impact on individual's attitude to contactless credit cards.

H3: An individual's attitude to contactless cards has a positive impact on individual's behavioral intention to use it.

H4: An individual's perceived usefulness has a positive impact on individual's behavioral intention to use contactless credit cards.

H5: An individual's perceived playfulness has a positive impact on individual's behavioral intention to use contactless credit cards.

H6: An individual's perceived risk has a negative impact on individual's behavioral intention to use contactless credit cards.

H7: An individual's perceived ease of use has a positive impact on individual's behavioral intention to use contactless credit cards.

\subsection{Research Methodology}

The aim of the study is to examine determinants of individuals' contactless credit cards adoption. We developed a theoretical model based on the TAM with added constructs PR and PP empirically tested its ability in predicting individual's' behavioral intention to use contactless credit cards. We comprised a 28 -items questionnaire (25 items relate to user acceptance of contactless credit cards and 3 are demographic questions) and used a five-point likert scale as a measurement scale for the study. We selected four cities (Istanbul, Ankara, Samsun, and Trabzon) in Turkey. After three-week survey in late July 2014, we collected the data. 750 surveys were distributed via 5 MBA students who were placed in public places such as the town-hall and 695 surveys were completed and returned.

Table 1: Demographics of Respondents

\begin{tabular}{lcc}
\hline Samples & $\boldsymbol{N}$ & Percentage \\
\hline Gender & & \\
\hline Male & 405 & 58,3 \\
\hline Female & 290 & 41,7 \\
\hline Age & & \\
\hline $18-25$ & 210 & 30,2 \\
\hline $26-35$ & 205 & 29,5 \\
\hline $36-45$ & 163 & 23,5 \\
\hline $46-55$ & 89 & 12,8 \\
\hline $55+$ & 28 & 4 \\
\hline
\end{tabular}


Table 1 continued

\begin{tabular}{lcc}
\hline Educational Background & & \\
\hline Primary School Graduate & 136 & 19,6 \\
\hline High-School Graduate & 272 & 39,1 \\
\hline University Graduate & 260 & 37,4 \\
\hline Post Graduate & 27 & 3,9 \\
\hline
\end{tabular}

The descriptive statistics of the respondents' demographic characteristics were analyzed and presented in Table 1. Of the 695 respondents, 58,3\% were male and 41,7\% were female; $30,2 \%$ were in the $18-25$ age group, $29,5 \%$ were in the $26-35,23,5 \%$ were in the $36-45,12,8 \%$ were in the 46-55 and 4\% were over 55. Also 19,6\% were primary school, 39,1\% were high school, $37,4 \%$ were university and $4 \%$ were post graduated.

The measures BI, A (Moon \& Kim, 2001), PU (Davis, 1989), and PEOU (Gefen et al., 2003), PP (Moon \& Kim, 2001) and PR (Krauter \& Faullant, 2008) were adapted from various studies related to the TAM. All items are shown in Appendix A. In the survey PEOU is measured by four items (PEOU1-4), PU by five items (PU1-5), A by four items (A1-4), BI by four items (BI1-4), PP is measured by four items (PP1-4), PR by four items (PR1-4). The Structural Equation Modeling (SEM) is used to analyze the causal relationship among variables, and to test the model fit of the hypothesis in order to verify the theoretical framework. SEM allows for simultaneous analysis to be performed for evaluating the relationships among variables that traditional regression technique cannot do (Teo, 2009).

\subsection{Measurement Model}

According to Kaiser (1974), higher KMO value than 0.7 means factor analysis is suitable. In the study, KMO value is higher than 0.80 , Bartlett's Test is significant indicating that the collected data is suitable for factor analysis. For the internal consistency, Cronbach's alpha is used. Hair et al. (1998) recommended that a higher than 0.7 reliability coefficient indicates reliability is high. In the study Cronbach's alpha values are higher than threshold of 0.7 , thus the validity and reliability are acceptable.

Table 2: Results of Exploratory Factor Analysis ${ }^{2}$

\begin{tabular}{|c|c|c|c|c|c|}
\hline & Factor 1 & Factor 2 & Factor 3 & Factor 4 & Factor 5 \\
\hline \multicolumn{6}{|c|}{ Perceived Ease Of Use (PEOU) } \\
\hline PEOU1 & 0,828 & & & & \\
\hline PEOU2 & 0,862 & & & & \\
\hline PEOU4 & 0,666 & & & & \\
\hline \multicolumn{6}{|c|}{ Perceived Usefulness (PU) } \\
\hline PU1 & & 0,684 & & & \\
\hline
\end{tabular}

2 PEOU3 item is removed due to results of factor analysis. 
Table 2 continued

\begin{tabular}{|c|c|c|c|c|c|}
\hline PU2 & & 0,824 & & & \\
\hline PU3 & & 0,753 & & & \\
\hline PU4 & & 0,556 & & & \\
\hline PU5 & & 0,551 & & & \\
\hline Perceived Playfulness (PP) & & & & & \\
\hline PP1 & & & 0,721 & & \\
\hline PP2 & & & 0,821 & & \\
\hline PP3 & & & 0,858 & & \\
\hline PP4 & & & 0,809 & & \\
\hline Perceived Risk (PR) & & & & & \\
\hline PR1 & & & & 0,848 & \\
\hline PR2 & & & & 0,909 & \\
\hline PR3 & & & & 0,925 & \\
\hline PR4 & & & & 0,824 & \\
\hline Attitude (A) & & & & & \\
\hline A1 & & & & & 0,751 \\
\hline A2 & & & & & 0,707 \\
\hline A3 & & & & & 0,781 \\
\hline A4 & & & & & 0,753 \\
\hline Eigenvalues & 3,188 & 3,165 & 3,1115 & 2,986 & 2,332 \\
\hline Explained Variance $(\%)$ & 15,939 & 15,826 & 15,576 & 14,930 & 11,659 \\
\hline Cumulative Explained Variance $(\%)$ & 15,939 & 31,765 & 47,341 & 62,271 & 73,930 \\
\hline $\begin{array}{l}\text { Kaiser- Meyer-Olkin (KMO) Measu } \\
\text { Adequacy }\end{array}$ & of Samp & & & 0,886 & \\
\hline Bartlett's Test $\quad \chi^{2}=9034$ & $: 190 \mathrm{p}$ & 000 & & & \\
\hline Cronbach's Alpha Values & 0,847 & 0,866 & 0,891 & 0,902 & 0,872 \\
\hline Total Cronbach's Alpha Value & & & & 0,886 & \\
\hline
\end{tabular}

Exploratory factor analysis (EFA) is utilized to reduce numerous latent variables to a more manageable set of factors no constraints are made on the factor loadings. EFA is carried out with the VARIMAX rotation option. As a consequence, six variables are extracted successfully and the total variance explained with the five components and 20 items accounts for 73,93\% of the total variance. For the further establishment of reliability, convergent validity, and discriminant validity of variables, confirmatory factor analysis (CFA) and EFA are performed. Table 3 shows the overall goodness of fit indices for the model. In the CFA, all the fit statistics are in the recommended area. 
Table 3: Fit Statistics of the Model

\begin{tabular}{lcc}
\hline Fit Statistics & Recommended & Obtained \\
\hline $\mathrm{x}^{2} / \mathrm{d} . f$. & $\leq 3,00$ & 2,392 \\
\hline GFI (Goodness of Fit Index) & $\geq 0,90$ & 0,964 \\
\hline AGFI (Adjusted Goodness of Fit Index) & $\geq 0,90$ & 0,944 \\
\hline CFI (Comparative Fit Index) & $\geq 0,90$ & 0,982 \\
\hline RFI (Relative Fit Index) & $\geq 0,90$ & 0,959 \\
\hline NFI (Normed Fit Index) & $\geq 0,90$ & 0,969 \\
\hline RMR (Root Mean Square Residual) & $0-1$ & 0,047 \\
\hline RMSEA (Root Mean Square Error of Approximation) & $\leq 0,08$ & 0,045 \\
\hline
\end{tabular}

Table 4 shows the values of the variables in the model of the maximum likelihood estimations (MLE), standard errors, critical ratios, AVEs and composite reliabilities. As can be seen from the Table 4 all the AVEs and composite reliabilities are higher than the recommended level of 0.60 and 0.50 respectively. AVEs are reported for PEOU $(0,78), \mathrm{PU}(0,58), \mathrm{PP}(\mathrm{O}, 73)$ and PR $(0,70)$ respectively (Nunnally \& Bernstein, 1994; Bagozzi \& Yi, 1988).

Table 4: Results of Model

\begin{tabular}{|c|c|c|c|c|c|c|}
\hline & Item & MLE & S.E. & C.R. & $\begin{array}{c}\text { Average } \\
\text { Variance } \\
\text { Extracted }\end{array}$ & $\begin{array}{l}\text { Composite } \\
\text { Reliability }\end{array}$ \\
\hline \multirow{5}{*}{$\begin{array}{l}\text { Perceived } \\
\text { Usefulness } \\
\text { (PU) }\end{array}$} & PU1 & 0,808 & & & \multirow{5}{*}{0,58} & \multirow{5}{*}{0,87} \\
\hline & PU2 & 0,760 & 0,046 & 19,795 & & \\
\hline & PU3 & 0,780 & 0,051 & 18,891 & & \\
\hline & PU4 & 0,752 & 0,056 & 16,825 & & \\
\hline & PU5 & 0,708 & 0,045 & 18,779 & & \\
\hline \multirow{4}{*}{$\begin{array}{l}\text { Perceived } \\
\text { Playfulness } \\
\text { (PP) }\end{array}$} & PP1 & 0,972 & 0,074 & 16,532 & \multirow{4}{*}{0,73} & \multirow{4}{*}{0,91} \\
\hline & PP2 & 0,849 & 0,051 & 20,634 & & \\
\hline & PP3 & 0,804 & 0,046 & 22,619 & & \\
\hline & PP4 & 0,770 & & & & \\
\hline \multirow{4}{*}{$\begin{array}{l}\text { Perceived } \\
\text { Risk (PR) }\end{array}$} & PR1 & 0,783 & 0,051 & 20,987 & \multirow{4}{*}{0,70} & \multirow{4}{*}{0,90} \\
\hline & PR2 & 0,891 & 0,50 & 24,154 & & \\
\hline & PR3 & 0,925 & 0,051 & 24,902 & & \\
\hline & PR4 & 0,745 & & & & \\
\hline \multirow{3}{*}{$\begin{array}{l}\text { Perceived Ease } \\
\text { of Use (PEOU) }\end{array}$} & PEOU1 & 0,898 & & & \multirow{3}{*}{0,78} & \multirow{3}{*}{0,92} \\
\hline & PEOU2 & 0,874 & 0,062 & 16,364 & & \\
\hline & PEOU4 & 0,882 & 0,063 & 16,778 & & \\
\hline
\end{tabular}


The composite reliability coefficients of the factors are also indicated in Table 4. All factors' composite reliabilities that are PU $(0,87)$, PP $(0,91)$, PR $(0,90)$ and PEOU $(0,92)$, higher than the threshold 0,70 (Nunnally \& Bernstein, 1994; Yap \& Khong, 2006). Also, all factor loadings show significant t-values, which means providing of convergent validity. Hence, the measurement model coefficient is in the acceptable limits, and it is concluded that model is reliable and valid.

\subsection{Structural Model}

Structural equation model can be estimated if the parameter value is reliable. It requires a supported model. For supporting the model is required to have the degree of freedom model is positive. Although no single index suggested various goodness of fit index cannot identify the correct model. Thus demonstrating the adequacy of the sample size in the study ( $\chi 2 / \mathrm{df})$ and fit indices (RMR, RMSEA, AGFI, GFI, NFI, CFI, RFI) are used.

All fit indices are shown in Table 5 and computed in the recommended area. In addition, $\operatorname{RMR}(0,072)$ and RMSEA $(0,048)$ are reported as it should be of value is below 0,08 (Reisinger \& Mavondo, 2006; Hooper et al. 2008; Yen et al. 2010).

\section{Table 5: Fit Indices of Structural Model}

\begin{tabular}{lcc}
\hline Fit Statistics & Recommended & Obtained \\
\hline $\mathrm{x}^{2} /$ d.f. & $\leq 3,00$ & 2,599 \\
\hline GFI (Goodness of Fit Index) & $\geq 0,90$ & 0,938 \\
\hline AGFI (Adjusted Goodness of Fit Index) & $\geq 0,90$ & 0,917 \\
\hline CFI (Comperative Fit Index) & $\geq 0,90$ & 0,968 \\
\hline RFI (Relative Fit Index) & $\geq 0,90$ & 0,936 \\
\hline NFI (Normed Fit Index) & $\geq 0,90$ & 0,949 \\
\hline RMR (Root Mean Square Residual) & $\leq 0,08$ & 0,072 \\
\hline RMSEA (Root Mean Square Error of Approximation) & $\leq 0,08$ & 0,048 \\
\hline
\end{tabular}

The findings support the acceptability of the structural model. AMOS output shows the parameters of the structural model is shown in Figure 3. 
Figure 3: The Parameters of the Structural Model

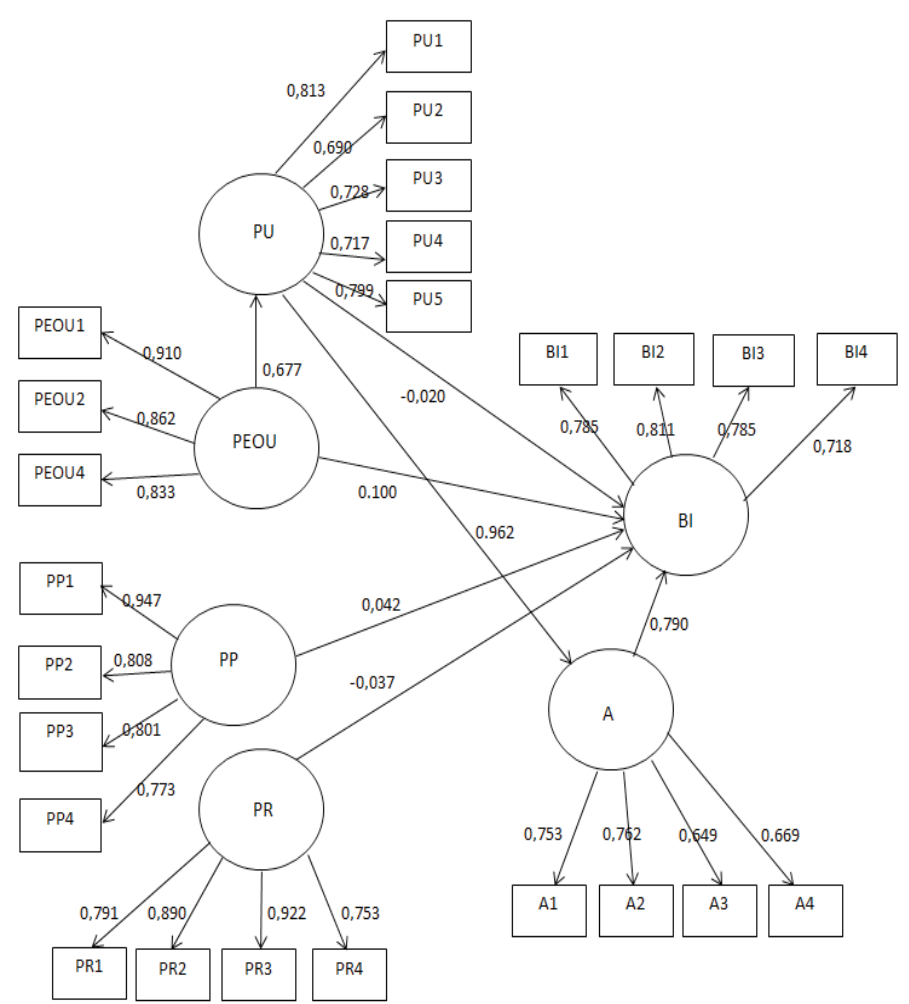

Structural model results confirm that PEOU has significantly impact on BI and A also has a significant impact on BI. The PU indirectly affects the BI. The path between BI and PR and PP is not significant. Table 6 shows the results of the structural model hypothesis testing.

Table 6: Structural Model Hypothesis Testing Results

\begin{tabular}{cccccc}
\hline & & MLE & S.E. & C.R. & Hypothesis Results \\
\hline PEOU & PU & 0,677 & 0,057 & $11,991 * * *$ & H1: Supported \\
\hline PU & A & 0,962 & 0,052 & $15,194 * * *$ & H2: Supported \\
\hline A & BI & 0,790 & 0,141 & $6,401 * * *$ & H3: Supported \\
\hline PU & BI & $-0,020$ & 0,111 & $-0,169$ & H4: Not Supported \\
\hline PR & BI & $-0,037$ & 0,022 & $-1,477$ & H5: Not Supported \\
\hline PP & BI & 0,042 & 0,042 & 0,915 & H6: Not Supported \\
\hline PEOU & BI & 0,100 & 0,036 & $2,594 * *$ & H7: Supported \\
\hline
\end{tabular}

$* * * \mathrm{p}<0,01 ; * * \mathrm{p}<0,05 ; * \mathrm{p}<0,10$. 
H1 is to test the relationship between the individual's PEOU and the individual's PU. According to the model, PEOU $(\beta=0,677)$ has a positive and significant effect on PU. Hence, hypothesis $\mathrm{H} 1$ is supported.

$\mathrm{H} 2$ is to test the relationship between the individual's PU and the individual's A. According to the model, $\mathrm{PU}(\beta=0,962)$ has a positive and significant effect on A. Hence, hypothesis $\mathrm{H} 2$ is supported.

$\mathrm{H} 3$ is to test the relationship between the individual's A and the individual's BI. According to the model, $\mathrm{A}(\beta=0,790)$ has a positive and significant effect on intention to use. Hence, hypothesis H3 is supported.

$\mathrm{H} 4$ is to test the relationship between the individual's PU and the individual's BI. According to the model, PU $(\beta=-0,020)$ has not a positive effect on intention to use and it is insignificant. Hence, hypothesis H4 is not supported.

H5 is to test the relationship between the individual's perceived risk and the individual's BI. According to the model, perceived risk $(\beta=-0,037)$ has a negative effect on intention to use but it is insignificant. Hence, hypothesis H5 is not supported.

H6 is to test the relationship between the individual's perceived playfulness and the individual's BI. According to the model, $\mathrm{A}(\beta=0,042)$ has a positive but insignificant effect on intention to use. Hence, hypothesis H6 is not supported.

$\mathrm{H} 7$ is to test the relationship between the individual's PEOU and the individual's BI. According to the model, PEOU $(\beta=0,100)$ has a positive and significant effect on intention to use. Hence, hypothesis $\mathrm{H} 7$ is supported.

\section{Conclusion}

In this study, it is aimed to determine the factors affecting the individuals' acceptance of contactless credit cards in Turkey. The results of this study verify that TAM is a useful tool in evaluating the BI contactless credit card technology. The strength of the causal relationships is analyzed by using SEM. As a consequence, it is obtained 5 factors that explain $73.9 \%$ of the total variance.

Findings showed that four hypotheses are significant: PEOU on PU (0.677), PU on attitude (0.962), attitude on intention to use and PEOU on BI (0.10). Individual's BI the technology is influenced by a positive attitude towards contactless credit cards use. Three of the hypotheses in this study, are not supported. In the research model, the paths from PU to BI, the path from perceived risk to BI, the path from perceived playfulness to BI are not significant. However, PU influenced BI indirectly through attitude towards contactless credit cards use. Moreover the path from PU to attitude is greater than the other paths (0.962). Attitude towards to use has stronger positive effect than PEOU for the BI technology. These results indicated that individuals will be more enthusiastic to use contactless credit card when they thought it is easy to use and efficient in payment. Hence for the success of the contactless payment system banks should emphasize that contactless payment is simpler than traditional payment methods 
and it would be better to let individuals to be aware of the benefits and efficiency of contactless payment. Also increasing to contactless payment systems is a required for push the individuals' acceptance.

Also surprisingly perceived risk and playfulness has not significant effect on intention to use. This situation might be explained by the indirect effect of PU on BI, which inhibits PR's negative influence on BI. PU could possibly reduce the negative consequences of risk perceptions of individuals by influencing BI indirectly. If queues are long, time savings could be important. Therefore, individuals may prefer fast payment advantages of contactless credit cards and it could be push individual adoption or individuals may think that they will never lose their cards. Despite the fact that contactless credit cards may improve security and minimize risk, some individuals might still believe that using contactless credit cards is risky, insecure and doubtful., Customers may be concerned about possible hijacking problems. Hence, overcoming security issues and increasing individuals' awareness of the safety factors inherent in contactless credit cards may enhance individuals' acceptance. The insignificant effect of the playfulness could be explained the direct effect of PEOU on BI. Individuals deem it is very easy to use, may thought it is not a funny side.

In the further studies adding different variables to the model for the acceptance of contactless credit card or a different information technology can be examined.

\section{Limitations}

Although the study provides important insights into the individuals' acceptance of contactless card, the study has some limitations. The first limitation is this study may not fully reflect the complexity of contactless card usage. Therefore, the results of the study should be analyzed as preliminary evidence. The second limitation is the sample size that study comprised of 697 individuals' responses. This sample is only a very small proportion of the entire population of Turkey. Therefore, studies with much larger sample size would be required to ensure appropriate generalization of the findings of the study. Lastly it is possible that should other factors are included in the model, a better fitting or more appropriate model might be identified.

\section{References}

Ajzen, I. (1991). The theory of planned behavior. Organizational Behavior and Human Decision Processes, 50, 179-211.

Ajzen, I., \& Fishbein, M. (1980). Understanding attitudes and predicting social behavior. Englewood Cliffs, NJ: Prentice-Hall.

Bagozzi, R., \& Yi, Y. (1988). On the evaluation of structural equation models. Journal of the Academy of Marketing Science, 16(1), 74-94.

Calli, L., Balcikanli, C., Calli, F., Cebeci, H. I., \& Seymen, O. F. (2013). Identifying factors that contribute to the satisfaction of students in e-learning. Turkish Online Journal of Distance Education, 14(1), 85-101.

Christiansen, P. (2011). Four important trends shaping the future of credit cards. First Data White Paper. First Data Corporation, 10p. 
Davis, F. D. (1989). Perceived usefulness, perceived ease of use, and user acceptance of information technology. MIS Quarterly, 13(3), 319-340.

Davis, F. D., Bagozzi, R. P. \& Warshaw, P. R. (1989). User acceptance of computer technology: A comparison of two theoretical models. Management Science, 35(8), 982-1003.

Featherman, M. S. \& Pavlou, P. A. (2002). Predicting e-services adoption: A perceived risk facets perspective. Proceedings of the eighth Americas conference on information systems, Dallas.

Fiedler,M., \& Ozturen, A. (2014). Online behavior and loyalty program participation-parameters influencing the acceptance of contactless payment devices. Research Journal of Applied Sciences Engineering and Technology, 7(15), 3188-3197.

Gefen, D., Karahanna, E., \& Straub, D. (2003). Trust and TAM in online shopping: An integrated model. MIS Quarterly, 27(1), 51-90.

Haberturk Newspaper. (2015). 04.01.2015, page 9/BKM-Interbank Crd Center-CEO Soner CANKO (Interview).

Hair J. F., Anderson R. E., Tatham, R. L. \& Black V. C. (1995). Multivarite data analysis with reading. Prentice Hall, International Inc, Viacorn Company, New Jersey.

Hair, J., Anderson, R., Tatham, R., \& Black, W. (1998). Multivariate data analysis. Upper Saddle River, NJ: Prentice Hall.

Handschuh, H. (2004). Contactless technology security issues. Information Security Bulletin, 9,95-100.

Harper, A. (2014). Case study of the impact on businesses and society by mobile contactless card technology. North central University Graduate Faculty of the School of Business and Technology Management, $\mathrm{PhD}$ dissertation, 126p.

Ho, E., Apostu, S., Michahelles, F., \& Ilic, A. (2013). Digital receipts: Fostering mobile payment adoption. Ambient Intelligence Lecture Notes, Computer Science, 8309, 140149 ,

Hooper, D., Coughlan, J., \& Mullen R. M. (2008). Structural equation modeling: Guidelines for determining model fit. The Electronic Journal of Business Research Methods, 6(1), 53-60.

Karaiskos, D. C., Kourouthanassis, P., \& Giaglis, G. M. (2007). User acceptance of pervasive information systems: Evaluating an RFID ticketing system. Proceedings of the 15th European Conference on Information Systems (ECIS), Athens, Greece, 1910-1921.

Grabner-Krauter, S., \& Faullant R. (2008). Consumer acceptance of internet banking: The influence of internet trust. International Journal of Bank Marketing, 26(7), 483-504.

Lee, Y., Kozar, K. A., \& Larsen, K. R. T. (2003). The technology acceptance model: Past, present, and future. Communications of AIS, 12, 752-780.

Lin, C. S., Wu, S., \& Tsai, R. J. (2005). Integrating perceived playfulness into expectationconfirmation model for web portal context. Information \& Management, 42, 683-693.

Mathieson, K. (1991), Predicting user intentions: comparing the technology acceptance model with the theory of planned behavior. Information Systems Research, 2(3), 173-191. 
Moon, J., \& Kim, Y. (2001). Extending the TAM for a world-wide-web context, Information \& Management. 38, 217-230.

Nunnally, J. C., \& Bernstein, I. H. (1994). Psychometric theory. New York: McGrawHill Inc.

Pikkarainen, T., Pikkarainen, K., Karjjaluoto, H., \& Pahnila, S. (2004). Consumer acceptance of online banking: An extension of the technology acceptance model. Internet Research, 14(3), 224-235.

Polasik, M., Wisniewski, T. P., \& Lightfoot, G. (2010). Modeling customers' intentions to use contactless cards. International Journal of Banking, Accounting and Finance, 4(3), 203-231.

Reisinger, Y., \& Mavondo, F. (2006). Structural equation modeling: Critical issues and new developments. Journal of Travel \& Tourism Marketing, 21(4), 41-71.

Shin, S., \& Lee, W. (2014). The effects of technology readiness and technology acceptance on NFC mobile payment services in Korea. The Journal of Applied Business Research, $30(6), 1615-1626$.

Smart Card Alliance. (2007). Contactless payments: Frequently asked questions. A Smart Card Alliance Contactless Payments Council Publication, 10p.

Taherdoost, H., \& Masrom, M. (2009). An examination of smart card technology acceptance using adoption model. 31st International Conference on Information Technology Interfaces (ITI), Cavtat, Croatia, 329-334.

Teo, T. (2009). Evaluating the intention to use technology among student teachers: Structural equation modeling approach. International Journal of Technology in Teaching and Learning, 5(2), 106-118.

Trutsch, T. (2014). The impact of contactless payment on spending. International Journal of Economic Sciences, 3(4), 70-98.

Wang, Y. (2008). Determinants affecting consumer adoption of contactless credit card: An empirical study. Cyber Psychology \& Behavior, 11(6), 687-689.

Wu, M. Y., Yu, P. Y., \& Weng, Y. C. (2012). A study on user behavior for I pass by UTAUT: Using Taiwan's MRT as an example. Asia Pacific Management Review, 17(1), 91-111.

Yap, B. W. \& Khong, K. W. (2006). Examining the effects of customer service management on perceived business performance via structural equation modeling. Applied Stochastic Models in Business and Industry, 22(5-6), 587-605.

Yen, D. C., Wu, C., Cheng, F., \& Huang, Y. (2010). Determinants of users' intention to adopt wireless technology: An empirical study by integrating TTF with TAM. Computers in Human Behavior, 26(5), 906-915.

Zheng, L., Favier, M., Huang, P., \& Coat, F. (2012). Chinese consumer perceived risk and risk relievers in e-shopping for clothing. Journal of Electronic Commerce Research, 13(3), 255-274. 


\section{Appendix (Survey Items)}

\begin{tabular}{|c|c|}
\hline PEOU1 & 1- I find it easy to get contactless credit card to do what I want it to do \\
\hline PEOU2 & 2- My interaction with contactless credit card is clear and understandable \\
\hline PEOU3 & 3- It will be impossible to use contactless credit card without expert help \\
\hline PEOU4 & 4- It is easy to remember how to use contactless credit card \\
\hline PU1 & 5- Using contactless credit card increases my task productivity \\
\hline PU2 & 6- Using contactless credit card supports the critical part of my tasks \\
\hline PU3 & 7- Using contactless credit card improves the performance of my tasks \\
\hline PU4 & 8- Using contactless credit card enables me to accomplish tasks more quickly \\
\hline PU 5 & 9- Overall, contactless credit card is useful for me to utilize shopping. \\
\hline A1 & 10- Using contactless credit card is a good idea. \\
\hline $\mathrm{A} 2$ & 11- Using contactless credit card is a pleasant idea. \\
\hline A3 & 12- In my opinion, it would be desirable to use the contactless credit card \\
\hline A4 & 13- Using contactless credit card is a wise idea. \\
\hline BI1 & 14- I would use the contactless credit card for my shopping needs. \\
\hline BI2 & 15- I will use contactless credit card on a regular basis in the future. \\
\hline $\mathrm{BI} 3$ & 16- I will frequently use contactless credit card in the future. \\
\hline $\mathrm{BI} 4$ & 17- I will strongly recommend others to use contactless credit card. \\
\hline PP1 & 18- Using contactless credit card gives enjoyment to me for my task. \\
\hline PP2 & 19- Using contactless credit card stimulates my curiosity. \\
\hline PP3 & 20- Using contactless credit card is exciting. \\
\hline PP4 & 21- Using contactless credit card gives fun to me for my task \\
\hline PR1 & $\begin{array}{l}\text { 22- I am afraid that other people might access to information about my shopping } \\
\text { transactions. }\end{array}$ \\
\hline PR2 & $\begin{array}{l}\text { 23- I believe it can rather easily happen that money is stolen if using contactless } \\
\text { credit card. }\end{array}$ \\
\hline PR3 & $\begin{array}{l}\text { 24- I am afraid that the confidentially of my financial transactions might get lost } \\
\text { when using contactless credit card. }\end{array}$ \\
\hline PR4 & 25- I think that privacy is not guaranteed when using contactless credit card. \\
\hline
\end{tabular}

